\title{
THE ROLE OF BANKS AND SECURITIES MARKETS IN THE POST-TRANSITION ECONOMIES OF EASTERN EUROPE
}

\author{
Sasho Arsov \\ Faculty of Economics - Skopje, Ss. Cyril and Methodius University \\ sarsov@eccf.ukim.edu.mk
}

\begin{abstract}
Economic theory predicts that the development of the financial sector should have a positive impact on the overall economic development. Research has predominantly confirmed this expectation, with the remark that at earlier stages of economic development this impact should be higher, while a disproportionate banking sector has detrimental effect on growth through its impact on attracting highly skilled workforce, increased presence of moral hazard and the associated banking crises. This issue has been studied only occasionally in the case of the former socialist economies of Central and Eastern Europe and the former USSR. This paper represents an attempt to analyze the impact of the banking sector and securities markets development on the economic growth of these countries. A sample of 22 countries is assembled, using data from 1995 to 2018 and a panel regression and a GMM technique are used to derive conclusions on the researched topic. The analysis has shown that the banking sector has played a positive role in the economic growth throughout the analyzed period, while the role of the stock market is not significant. This is in line with the previous studies which have confirmed that the positive role of the securities markets should be expected only at higher levels of economic development. Also, the impact of the overall financial sector is deemed to be positive.
\end{abstract}

Keywords: Financial development, Banking sector, Financial markets, Post-transition.

JEL classification: 016

\section{INTRODUCTION}

The role of the financial sector in the economic development has been researched thoroughly (King and Levine, 1993; Levine and Zervos, 1998; Rajan and Zingales, 1998; Fisman and Love, 2004). The main dilemma attracting scholars' attention is whether the development of the financial sector is really contributing to the overall economic development or they both follow mutually unrelated pathways. In addition to the overall financial development, it was the structure of the financial sector that had been in the focus of numerous studies in terms of the optimal share of the banking sector and the stock market and their role as complements or counterparts.

The above issues in the case of the economies that underwent the process of economic transition from socialism to market economy have been researched only to a limited extent (Berglöf and Bolton, 2002; Koivu, 2002; Kenourgios and Samitas, 2007; Bonin and Wachtel, 2008; Cojocaru et al., 2016). However, most of these studies have been prepared relatively early and subsequently the time periods covered by them are rather short. Therefore, having in mind the dynamics of the changes these countries are still undergoing, their results, with all due respect, need to be reconsidered as new data become available.

These countries present a great opportunity to investigate the impact of financial development due to the compressed time period during which this process has been evolving and the exceptionally

http://doi.org/10.47063/EBTSF.2020.0007

http://hdl.handle.net/20.500.12188/9677 
low starting point for the observation of such an intensive social transformation. Namely, in the centrally-planned economies stock markets did not exist and the banking sectors were based on completely different principles from those in the market-based economies. Banks most often served as monetary transmission mechanisms, with the central banks (and the governments) directing the flows of money to certain economic sectors. The allocation of capital was mostly based on political, rather than economic principles, so that when these countries entered the process of transition, their banks lacked the expertise needed to properly address the needs of the business sector. Additionally, in some countries the banks were soon plagued by non-performing loans as a result of the flawed process of credit allocation and the collapse of numerous companies and entire industrial sectors due to the changed economic reality, military conflicts, disruption of market connections, etc.

This paper aims to fill a part of the gap by analyzing the countries in Eastern Europe that entered a process of transition in the 1990s and for which data have been available. The period covered is 1995-2018 and its length provides us with an opportunity to obtain longer time-series of consistent data, reflecting the processes of transition to competitive banking sectors and the privatization as the basis for the operation of the respective stock markets.

Some of the studies on this topic covering the transition economies focus on the role of the banking sector (Koivu, 2002; Petkovski and Kjosevski, 2014; Bonin et al., 2014), while others include the coexistence between banks and securities markets (Berglöf and Bolton, 2002; Kenourgios and Samitas, 2007; Fink et al., 2009), but the early stages of transition covered provide little basis for deriving workable conclusions. This paper adopts the broader approach in order to come up with a more comprehensive picture encompassing the financial sector as a whole. We believe that the time period since the inception of the stock markets in these countries has now been sufficiently long to provide us with relevant time series of data. Additionally, in order to avoid the impact of economic cycles, the 24-year time period is divided into non-overlapping three-year periods, which is also a novelty since most of the studies use five-year periods. We believe that the 3-year period is sufficiently comprehensive for this purpose, at the same time providing us with elongated series of data for the intended analysis ( 8 periods compared to 5 in five-year intervals).

The database has been assembled using several reliable sources (as explained bellow in the Data and methodology section) and as such, it represents a panel of data for 22 countries. The initial sample of 26 countries shrank to 22 due to the unavailability of data for some countries for various reasons (e.g. there is no stock exchange in Albania). Panel regressions and Generalized Method of Moments (GMM) are applied to come up to conclusions about the role of banking sectors and stock markets in the transition and post-transition economies in the three decades past the collapse of

socialism. It is expected that the conclusions drawn in this study will provide a useful input for the pro-growth policies with respect to the development and structuring of the financial systems.

The paper is structured as follows. First, a review of the most relevant literature in the field is elaborated. The selection from the abundant corpus of related papers is chronologically presented, while paying attention to the articles covering the same group of countries. The next section describes the database used, its sources and the methodology of the research. It also contains a discussion of the results, while the last section covers the conclusions of the analysis, policy recommendations and recommendations for further research.

\section{LITERATURE REVIEW}

The earliest efforts to investigate the association between financial sector development and economic growth are made by Schumpeter (1912) and later by Goldsmith (1969), while a more 
recent wave of research begins in the 1990s with the works of King and Levine (1993), Fry (1997) and Levine and Zervos (1998). With the availability of larger and more reliable databases and the econometric technics capable of capturing the endogeneity issues, the research has moved from theoretical to empirical, most often cross-country studies, testing the causality between various financial development indicators and the economic development. Some of the studies refer to a particular group of countries, while others are broad-based with the limitation that the development of the financial sectors and especially that of the stock markets have not been occurring simultaneously throughout the world, most notably in the former socialist economies.

Although the theoretical assertions and empirical conclusions are not undisputed, the prevailing view among researchers is that the development of the financial sector has positive impact on economic growth. The benefits of the developed financial sector are manifold, such as the mobilization of financial resources from various sources resulting in an increase of the overall amount of capital available for investments (McKinnon 1973; Greenwood and Jovanovic, 1990), provision of capital at lower cost for the investing companies (Rajan and Zingales, 1998), allocation of capital to its most efficient uses (King and Levine, 1993; Levine, 1997; Mishkin, 2002), efficient and innovative payment services (Kindleberger, 1993), financing of high-risk projects through diversification of risk, contribution to the capital account and trade liberalization (Edwards, 2001), etc.

Since the growth of the financial sector is itself a component of the rate of growth of GDP, Ductor and Grechyna (2015) explore the relationship between financial development and real output growth and conclude that the impact of financial development is optimal as long as the two sectors move together. When private credit increases rapidly, its effect on economy turns negative. Similarly, Rioja and Valev (2004) explore the impact of financial development on the sources of growth and find that in less developed economies the impact on economic growth goes through capital accumulation, while in the industrialized countries, the financial development affects productivity growth. On the other hand, when financial development surpasses the pace of overall economic development, it becomes detrimental to it, because it attracts high-quality labour force, the large financial sector produces higher levels of moral hazard ("too big to fail"), the frequency of boom-bust cycle increases, etc. (Gambacorta et al., 2014; Sahay et al., 2015). The results of Mhadhbi (2014) are far less conclusive, indicating that the direction of the relationship varies with the sample studied and the nature of the indicators used as proxies.

One of the dilemmas overburdening the entire line of thought is the possibility of bidirectional causality between financial and economic development. Researchers logically deduce that the higher level of economic development demands higher level of financial services but also the conditions for financial development are far more available in the developed economies in terms of financial resources, human capital, informational infrastructure, etc. (Robinson, 1952; Lewis, 1955). Since there is no clear-cut resolution regarding the direction of this impact, these influences are assumed to occur simultaneously in both directions, which is also reflected in the econometric techniques used to explore them.

Additionally, one of the most intriguing issues in this area is the structure of the financial system and not its overall development per se. Namely, as economic and financial systems develop, the latter not only grows in size, but also diversifies its structure through the emergence of new institutions, participants, instruments and practices. Researchers have attempted to determine whether the relative share of the most important components of the financial system, banks and securities markets and their interrelationship is relevant and if it is related to the stage of economic development. Goldsmith (1969) in his comparative analysis reaching back to the mid-1 $19^{\text {th }}$ century and covering 35 countries, including two socialist economies (USSR and Yugoslavia), comes to a 
conclusion that financial intermediation increases in the course of development, while the share of banks in the financial intermediation drops in the later stages of economic development. A similar outcome is achieved by Demirgüç-Kunt et al. (2013). They implement a specific quantile regression on a sample of 72 countries to find out that as countries develop, the importance of banks diminishes, while the importance of financial markets increases.

The relative importance of banks and securities markets has been explored not only in relation with the level of development, but also with respect to the legal origin and the associated corporate governance systems. Traditionally, Anglo-Saxon countries with common law practice have been considered more market-oriented, while countries with civil law systems as bank-based economies. There has been a long debate regarding the comparative efficiency of both systems, but the practice denies the majority of the arguments, since the USA, UK, Germany and Japan belong to different groups and all of them are highly developed economies. Banks and capital markets should not necessarily be considered competitors. Song and Thakor (2010) in a theoretical paper depict three forms of interaction between banks and capital markets: competition, complementarity and coevolution. The process of securitization is assisted by the banks' financial analysis which provides investors with valuable insight that lowers their investment risks. On the other hand, higher bank equity capital enables banks to expand their credit activity, thus further increasing the share of the banking sector. However, La Porta et al. (2000) reject the entire debate with the conclusion that it is overall financial development, and not financial structure that are important for the economic advancement of a country or a company.

The focus of this paper are the economies in Central and Eastern Europe (CEE) (including the Commonwealth of Independent States (CIS) countries) which began their transition into market economies after the collapse of socialism in 1990. They represent a very convenient field for exploration of the financial sector development, since they entered this process from nearly a zero starting point as their previous banking systems were centralized, sometimes operating as monobank systems, which mostly served the purpose of allocating state funds in the form of credit to the state-owned businesses. As a result, with the beginning of the transition, these banks needed intensive restructuring to enable them to operate under market conditions and in some cases they ended up flooded with non-performing loans because of the collapse of their debtors during the early nineties. In many of the countries, the period was marked with a dramatic rise in the number of banks, to a large extent assisted by the inflow of foreign capital in the banking sector (Bonin et al., 2014). The stock market did not exist at all and the process of privatization occurring in the same period was supposed to create preconditions for the opening and operations of the securities markets.

The number of studies exploring this problem in the CEE countries is relatively low. Also, most of them were published when the time-series were quite short to provide the basis for deriving sustainable conclusions. Most of the studies focus on the banking sector, with only a few of them involving the securities markets and their conclusions are mixed to a large extent. In one of the earliest efforts, the results of Koivu (2002) about the impact of the rising credit activity on growth are inconclusive, but the interest rate margin has the expected negative sign. Berglöf and Bolton (2002) also do not find real support for the thesis that finance has contributed to increased growth in the transition countries in the first decade of transition. The banking sectors were dominated by foreign banks, while the stock markets are assessed as illiquid and barely sustainable. The results of the Johansen's cointegration technique applied by Kenourgios and Samitas (2007) point to a significant impact of bank credit on economic growth, but the role of the stock market liquidity is insignificant. Fink et al. (2009) analyze 9 EU-accession countries and find that financial market segments which are linked to the public sector positively contribute to the economic growth, but 
the period covered 1996-2000 could be the reason for the insignificant role of the stock market in this respect. Petkovski and Kjosevski (2014) apply GMM technique on a sample of 16 transition economies and conclude that the growth of private credit had a negative impact on economic growth in these countries, while the broader ratio of quasi-money had a positive impact.

\section{DATA AND METHODOLOGY}

\subsection{Data and proxy measures}

For the purposes of the analysis, a database was created comprising 26 CEE and CIS countries, but because of missing data on some crucial variables, 4 countries have been exempt and the final sample consists of 22 countries. The data cover the period 1995-2018 which corresponds to the period of transition and afterwards, but it also reflects the possibility to obtain relevant data regarding the banking systems and the capital markets which became operational after the first wave of privatization.

The data used in the analysis were assembled from several sources. Most of the data were obtained from the World Bank's World Development Indicators Database and the Global Financial Development Database, the IMF Financial Development Index database, while the data regarding the Human capital index were obtained from the Penn World Tables and the Capital Account Openness Index (KAOPEN) was taken from Chinn and Ito (2006).

The basic goal of the paper is to determine the impact of the two basic components of the financial system - banks and stock markets on economic growth and thus derive a conclusion about the relative importance of each of them for the economic development of the countries in transition. Having in mind that the economic development is a result of multiple factors, our basic model contains several control variables in addition to those that are our basic concern. In order to maintain comparability of our results within the broader corpus of research on this topic, we apply the widely used measures as proxies for economic and financial development.

The goal of the study implies that economic growth is used as a dependent variable and its most appropriate measure is the annual rate of growth of real GDP per capita.

The independent variables consist of variables representing financial development and a set of control variables generally used to represent other factors determining economic growth. We use several measures related to financial development:

- The level of financial development is usually represented by the size of the banking activity and the activity on the stock market. With respect to the banking activity, we use the amount of credit extended by banks to the private sector divided by GDP.

- The development of the stock market is represented by the total value traded in the stock market divided by GDP.

- Additionally, we use the amount of liquid liabilities divided by GDP, which is a measure of the overall size of the financial sector, i.e. the liquidity of the economy. This variable equals currency plus demand and interest-bearing liabilities of banks and non-bank financial intermediaries divided by the GDP.

The review of a broad corpus of relevant literature pointed that there is a selection of generally accepted control variables. The most frequently used variables include the initial level of GDP per capita, the size of government consumption, the rate of inflation, international openness of the economy, investments in fixed assets, human capital, etc. 
- Initial GDP per capita. This is the lagged level of GDP per capita for the country. Economic theory predicts that the national economies move toward convergence, so that the expected sign is negative when growth is the dependent variable or positive when the level of GDP is the dependent variable.

- Government consumption. It is used to reflect the impact of government spending on GDP and its contribution toward accelerated economic growth. It is represented by the total government expenditures on final goods and services as a share of GDP, but the sign of this variable is indeterminate since it depends on the efficiency of the macroeconomic policies.

- Inflation. High inflation is expected to have a detrimental effect on growth, but no inflation or negative inflation are also considered impediments to economic growth. Having in mind the episodes of high and even hyperinflation among the transition economies, we expect a negative sign of this variable.

- International openness of the economy. The higher degree of internationalization of the economy is expected to have a positive impact on economic growth since the increased level of imports is usually linked to higher demand of inputs for the manufacturing and services sectors, while increased exports are a sign of the rising degree of competitiveness of the domestic economy. This variable is represented by the sum of total imports and exports as a share of GDP.

- Human capital. Countries with higher quality education and higher share of educated population are expected to exhibit higher growth rates. This variable is usually represented by the so-called human capital index, based on the average years of schooling and the returns to education. We take this variable from the Penn Tables because of the more complete data.

- Crisis. In order to capture the influence of periodic financial crises on economic growth, we use the indicator crisis as a dummy variable, which takes the value of 1 if a country went through a financial crisis in a particular three-year period and zero otherwise. The information for this variable was obtained from the World Bank Global Financial Development Database.

- EU membership. Assuming that the membership in the European Union has had some positive impact on economic growth for the countries which achieved full membership during the analyzed period, we include this variable as a dummy variable which takes a value of 1 for the period of full membership of a country and 0 otherwise.

- Capital account openness. The degree of openness of the capital account is measured by the index initially introduced in Chinn and Ito (2006). KAOPEN is based on the binary dummy variables that codify the tabulation of restrictions on cross-border financial transactions reported in the IMF's Annual Report on Exchange Arrangements and Exchange Restrictions (AREAER).

Most of these variables are used in the panel regression, while for the GMM models, a selection of them is applied, to avoid the problem of excessive number of instruments.

\subsection{Methodology}

In order to avoid the impact of business cycles, it is customary in studies of this kind to use fiveyear averages for the variables in the model. We change this a little in order to obtain a richer timeseries by using 3-year averages, so that the entire 24-year period is transformed into a series of eight observations per variable per country. Therefore, we obtain a panel of data and in the analysis we implement econometric techniques appropriate for this kind of datasets. 
In order to control for unobserved country-specific effects, we use a dynamic panel procedure. The first estimate is therefore made using panel regression with country-fixed effects. However, as mentioned above, we face the problem of endogeneity of data, since the explanatory variables are also affected by the dependent variable. In other words, it is widely accepted that more highly developed economies have better developed financial systems and that the economic growth in the past has contributed to the financial development itself. The same can be said about human capital, international trade, etc. In order to overcome this problem, the dynamic panel GMM econometric tool is used, first described by Arrelano and Bond (1991) and further developed in Arrelano and Bover (1995), Blundell and Bond (1998).

The basic equation of interest is:

$$
y_{i, t}-y_{i, t-1}=(\alpha-1) y_{i, t-1}+\beta F D_{i, t}+\gamma X_{i, t}+\eta_{i}+\mu_{t}+\varepsilon_{i, t}
$$

Where $y_{t}$ is natural logarithm of real GDP per capita in country $i$ in period $t, y_{t-} y_{t-1}$ is the growth rate of real per capita GDP, $\mathrm{FD}_{\mathrm{i}, \mathrm{t}}$ is a measure of financial development, $\mathrm{X}_{\mathrm{i}, \mathrm{t}}$ is a set of control variables, $\eta_{i}$ are unobserved and country-specific fixed effects, $m_{t}$ are unobserved time-specific effects and $\varepsilon_{i, t}$ is the error term.

Equation (1) can be rewritten as:

$$
y_{i, t}=\lambda y_{i, t-1}+\beta F D_{i, t}+\gamma X_{i, t}+\eta_{i}+\mu_{t}+\varepsilon_{i, t}
$$

The above equation poses several problems: first, it is the existence of country-specific effects, and second, there is a likely endogeneity of most of the regressors with growth as a dependent variable, so we must control the issue of reverse causation. Classical panel regression models do not address these issues and thus we apply the first-difference GMM model proposed by Arrelano and Bond (1991), by using lagged values of explanatory variables as instruments. Period effects can be solved by using time-specific dummy variables. After first-differencing equation (2), it obtains the form:

$y_{i, t}-y_{i, t-1}=\lambda\left(y_{i, t-1}-y_{i, t-2}\right)+\beta\left(F D_{i, t}-F D_{i, t-1}\right)+\gamma\left(X_{i, t}-X_{i, t-1}\right)+\left(\varepsilon_{i, t}-\varepsilon_{i, t-1}\right)$

Since the new error term is correlated with the lagged dependent variable and there is still the endogeneity problem, the use of instruments is required to overcome these problems. The instruments should be variables that are correlated with the endogenous variables, but not directly with the dependent variable. For simplicity, lagged values of the independent variables are often used as instruments.

In this case, we implement a dynamic panel regression using OLS and GMM methods. The OLS is used only for comparison of the results.

\section{RESULTS AND DISCUSSION}

First, in Table 1we present the descriptive statistics of the variables. We can observe certain large discrepancies among the variables, depicting the divergent economic performances of the group of countries with relatively similar economic background. However, when interpreting panel data we need to have in mind that the mean values and deviations represent various units (countries) and various periods. In this case, the data used are 3-year averages per country and not annual data. 
Table 1: Descriptive statistics

\begin{tabular}{|l|c|c|c|c|c|c|c|c|}
\hline & $\begin{array}{c}\text { Growth of } \\
\text { per capita } \\
\text { GDP } \\
\text { (natural log) }\end{array}$ & $\begin{array}{c}\text { GDP per } \\
\text { capita } \\
\text { (natural } \\
\text { log) }\end{array}$ & $\begin{array}{c}\text { Credit to } \\
\text { private } \\
\text { sector by } \\
\text { banks/GDP }\end{array}$ & $\begin{array}{c}\text { Value of } \\
\text { stocks } \\
\text { traded / } \\
\text { GDP }\end{array}$ & $\begin{array}{c}\text { Import + } \\
\text { Exports / } \\
\text { GDP }\end{array}$ & $\begin{array}{c}\text { Govern- } \\
\text { ment } \\
\text { expenditure/ } \\
\text { GDP }\end{array}$ & $\begin{array}{c}\text { Rate of } \\
\text { inflation }\end{array}$ & $\begin{array}{c}\text { Human } \\
\text { capital index }\end{array}$ \\
\hline Mean & 0.110 & 8.749 & 36.319 & 4.357 & 99.884 & 17.809 & 7.603 & 3.178 \\
\hline Median & 0.104 & 8.897 & 36.320 & 1.359 & 96.166 & 18.352 & 4.908 & 3.166 \\
\hline Maximum & 0.374 & 10.153 & 91.361 & 69.847 & 187.561 & 25.598 & 65.001 & 3.780 \\
\hline Minimum & -0.087 & 6.449 & 3.399 & 0.001 & 35.272 & 9.732 & -0.210 & 2.744 \\
\hline St. deviation & 0.081 & 0.906 & 20.250 & 7.932 & 32.515 & 3.126 & 10.004 & 0.225 \\
\hline Skewness & 0.215 & -0.641 & 0.275 & 4.576 & 0.3582 & -0.595 & 3.274 & 0.331 \\
\hline Kurtosis & 3.169 & 2.529 & 2.498 & 33.107 & 2.573 & 3.435 & 15.168 & 2.655 \\
\hline & & & & & & & & \\
\hline Observations & 154 & 154 & 154 & 154 & 154 & 154 & 154 & 154 \\
\hline
\end{tabular}

(Source: Author's calculations)

Table 1 shows that the share of credit extended by banks to private sector in GDP ranges between $3.4 \%$ and $91 \%$ as an average value for a 3 -year period per country. The value traded on the stock market is also marked with huge deviations which are the result of their immaturity and the data from the very beginnings of these markets which are included in the time series. The rate of inflation depicts also episodes of very high inflation in some countries, such as $95 \%$ in Serbia in 1996 and 2001, 176\% in Armenia in 1996, up to 1.058\% in Bulgaria in 1997.

\subsection{Panel regression}

Next, we present the results of the panel regression using OLS method. Although the main focus is on the data from the difference GMM technique, we will use these as a first reference. For this purpose, several regression equations have been estimated, employing various variables as determinants. The first two columns show the results using growth and the next two use the level of GDP per capita as dependent variables.

Table 2: Panel regression results using OLS

\begin{tabular}{|c|c|c|c|c|}
\hline & $\begin{array}{c}\text { Model } 1 \\
\text { Dependent } \\
\text { variable Growth }\end{array}$ & $\begin{array}{c}\text { Model } 2 \\
\text { Dependent } \\
\text { variable Growth }\end{array}$ & $\begin{array}{c}\text { Model } 3 \\
\text { Dependent } \\
\text { variable GDP }\end{array}$ & $\begin{array}{c}\text { Model } 4 \\
\text { Dependent } \\
\text { variable GDP }\end{array}$ \\
\hline Constant & $\begin{array}{r}1.6033^{* * *} \\
(0.0025) \\
\end{array}$ & $\begin{array}{r}1.4989^{* * *} \\
(0.002)\end{array}$ & $\begin{array}{r}1.6033 * * * \\
(0.002)\end{array}$ & $\begin{array}{r}1.4989^{* * *} \\
(0.002)\end{array}$ \\
\hline Initial GDP per capita $\left(\mathrm{GDP}_{\mathrm{t}-1}\right)$ & $\begin{array}{r}-0.1955^{* * *} \\
(0.0001) \\
\end{array}$ & $\begin{array}{r}-0.1752 * * * \\
(0.0002) \\
\end{array}$ & $\begin{array}{r}0.8044 * * * \\
(0.000) \\
\end{array}$ & $\begin{array}{r}0.8247 * * * \\
(0.000) \\
\end{array}$ \\
\hline Bank credit to private sector " & $\begin{array}{r}0.0074 \\
(0.585) \\
\end{array}$ & & $\begin{array}{r}0.0074 \\
(0.585)\end{array}$ & \\
\hline Stock traded to GDP “" & $\begin{array}{r}0.0127^{* *} \\
(0.022) \\
\end{array}$ & & $\begin{array}{r}0.0127 * * \\
(0.022) \\
\end{array}$ & \\
\hline Liquid assets to GDP " & & $\begin{array}{r}-0.0137 \\
(0.586) \\
\end{array}$ & & $\begin{array}{l}-0.0137 \\
(0.586) \\
\end{array}$ \\
\hline Trade openness “ & $\begin{array}{l}-0.0164 \\
(0.564)\end{array}$ & & $\begin{array}{l}-0.0164 \\
(0.564)\end{array}$ & \\
\hline Capital account openness & & $\begin{array}{r}0.0019 \\
(0.797)\end{array}$ & & $\begin{array}{l}0.0019 \\
(0.797)\end{array}$ \\
\hline
\end{tabular}




\begin{tabular}{|c|c|c|c|c|}
\hline Inflation “ & $\begin{array}{r}-0.0913 \\
(0.229) \\
\end{array}$ & $\begin{array}{r}-0.1429 \\
(0.069) \\
\end{array}$ & $\begin{array}{r}-0.0913 \\
(0.229) \\
\end{array}$ & $\begin{array}{r}-0.1429 \\
(0.069) \\
\end{array}$ \\
\hline Government expenditure “ & $\begin{array}{r}-0.0889 * * \\
(0.047)\end{array}$ & $\begin{array}{r}-0.0913 * * \\
(0.042)\end{array}$ & $\begin{array}{r}-0.0889 * * \\
(0.047)\end{array}$ & $\begin{array}{r}-0.0913 * * \\
(0.042)\end{array}$ \\
\hline Financial crisis & $\begin{array}{r}-0.0332 * * \\
(0.020) \\
\end{array}$ & $\begin{array}{r}-0.0276^{* *} \\
(0.054) \\
\end{array}$ & $\begin{array}{r}-0.0332 * * \\
(0.020) \\
\end{array}$ & $\begin{array}{r}-0.0276^{* *} \\
(0.054) \\
\end{array}$ \\
\hline Human capital & $\begin{array}{r}0.1617 * * * \\
(0.006) \\
\end{array}$ & $\begin{array}{r}0.1444^{* *} \\
(0.016) \\
\end{array}$ & $\begin{array}{r}0.1617 * * * \\
(0.006) \\
\end{array}$ & $\begin{array}{r}0.1444 * * \\
(0.016) \\
\end{array}$ \\
\hline EU membership & $\begin{array}{r}-0.0136 \\
(0.423)\end{array}$ & $\begin{array}{r}-0.0299 \\
(0.123)\end{array}$ & $\begin{array}{r}-0.0136 \\
(0.423)\end{array}$ & $\begin{array}{r}-0.0299 \\
(0.123)\end{array}$ \\
\hline & $\begin{array}{c}\text { Cross section and } \\
\text { period fixed } \\
\text { effects }\end{array}$ & $\begin{array}{c}\text { Cross section and } \\
\text { period fixed } \\
\text { effects }\end{array}$ & $\begin{array}{l}\text { Cross section } \\
\text { and period } \\
\text { fixed effects }\end{array}$ & $\begin{array}{l}\text { Cross section } \\
\text { and period } \\
\text { fixed effects }\end{array}$ \\
\hline DW statistics & 1.59 & 1.62 & 1.58 & 1.62 \\
\hline $\mathrm{R} 2$ & 0.748 & 0.736 & 0.998 & 0.998 \\
\hline $\begin{array}{l}\text { Wald test for joint significance } \\
\text { (p-value) }\end{array}$ & 0.0000 & 0.0000 & 0.0000 & 0.000 \\
\hline
\end{tabular}

Standard errors in parentheses.

$*, * *, * * *$ - denote significance at $10 \%, 5 \%$ and $1 \%$ respectively

"Variables are used as natural logarithms of the respective values

The basic difference between the models is that models 1 and 3 use regressors representing the banking sector and the stock market separately, while models 2 and 4 use total liquidity as an indicator of the overall financial development. Also, models 1 and 3 use trade openness of the country as a regressor, while models 2 and 4 use capital account openness.

The results of the regressions are very interesting. As expected, past GDP per capita is negatively related to future growth, indicating a process of convergence among the economies in the sample. When the level of GDP is used as a dependent variable, past GDP levels have a positive sign, which is not surprising as countries with higher levels of GDP in the past still have higher GDP levels in the future (convergence means that the differences are shrinking relatively). Another interesting fact is that the values of all the other regressors, the intercepts and the standard errors are the same in models 1 and 3, and also in 2 and 4, respectively, which we will refer to back again later in the GMM model estimates.

The remaining indicators do not provide very valuable information as financial indicators are considered. Only the stock market has a significant positive sign, indicating its positive impact on growth, which we take with little confidence. The other significant regressors are quite as expected with crisis periods having negative impact on growth rates, human capital positively influencing growth and higher inflation having certain negative impact. The negative sign of government expenditure can be assigned to inefficient and possibly irresponsible macroeconomic spending during the transition and post-transition years. The insignificant value of the EU membership regressor is expected, since the positive effects of accession to the European Union might be linked even earlier, during the pre-accession period, which is not captured by this variable alone.

\subsection{Generalized Method of Moments estimate}

As previously explained, studies on economic growth based on simple panel regression estimates suffer from a serious weakness - endogeneity of the variables, i.e. the reverse causality between the dependent variable and at least some of the regressors. In this case, it is widely expected that 
more developed countries would have better developed financial systems, but also such countries have better educational systems and thus higher human capital ratios, developed economies are usually preferred partners in international trade, etc. In order to cope with this issue, we apply the GMM technique, which provides a solution to the problem of endogeneity. More specifically, we apply the first difference GMM model (Arellano and Bond, 1991) in which the first differences of the variables are regressed, as explained above. Since the sample contains a small number of periods (8), we apply a dynamic panel GMM model. We use the second lags in levels of the variables as instruments, while for the lagged GDP, we use its dynamic form as an instrument, with lags between period t-2 and t-4). In order to avoid the problem of excessive number of instruments, we shorten the model by excluding the EU membership as a variable. To avoid period-specific effects, time dummies are included. To test the adequacy of the model and the validity of the results, we apply the Sargan test of overidentifying restrictions and the second-order serial correlation of the residuals in first differences.

Models 1, 2 and 3 use real GDP growth as a dependent variable, while model 4 uses real GDP per capita. In model 1, the financial sector is represented by the banking sector and the securities market, in model 2 it is proxied by the total liquid assets, while in model 3 only the banking sector is included.

The results of the first difference dynamic panel GMM model are presented in table 3.

Table 3: GMM model results

\begin{tabular}{|c|c|c|c|c|}
\hline & $\begin{array}{l}\text { Model } 1 \\
\text { Dependent } \\
\text { variable: } \\
\text { Real GDP } \\
\text { Growth }\end{array}$ & $\begin{array}{l}\text { Model } 2 \\
\text { Dependent } \\
\text { variable: } \\
\text { Real GDP } \\
\text { Growth }\end{array}$ & $\begin{array}{l}\text { Model } 3 \\
\text { Dependent } \\
\text { variable: } \\
\text { Real GDP } \\
\text { Growth }\end{array}$ & $\begin{array}{c}\text { Model } 4 \\
\text { Dependent } \\
\text { variable: } \\
\text { Real GDP }\end{array}$ \\
\hline Initial GDP per capita “ & $\begin{array}{r}-0.5358 * * * \\
(0.000) \\
\end{array}$ & $\begin{array}{r}-0.6562 * * * \\
(0.000) \\
\end{array}$ & $\begin{array}{r}-0.560 * * * \\
(0.000) \\
\end{array}$ & $\begin{array}{r}0.2739 * * * \\
(0.002) \\
\end{array}$ \\
\hline Credit to private sector / GDP" & $\begin{array}{r}0.0750 * * \\
(0.034)\end{array}$ & & $\begin{array}{r}0.088 * * \\
(0.014)\end{array}$ & $\begin{array}{r}0.0750 * * \\
(0.034)\end{array}$ \\
\hline Stocks traded / GDP “ & $\begin{array}{r}0.0222 \\
(0.330)\end{array}$ & & & $\begin{array}{l}0.0222 \\
(0.330)\end{array}$ \\
\hline Liquid assets / GDP “ & & $\begin{array}{r}0.1521^{* * *} \\
(0.000) \\
\end{array}$ & & \\
\hline Trade openness " & $\begin{array}{r}-0.1704 * * \\
(0.015)\end{array}$ & $\begin{array}{r}-0.1372 * * * \\
(0.001)\end{array}$ & $\begin{array}{r}-0.0921 * * \\
(0.030)\end{array}$ & $\begin{array}{r}-0.1704 * * \\
(0.015)\end{array}$ \\
\hline Inflation “ & $\begin{array}{r}0.1687 \\
(0.514) \\
\end{array}$ & $\begin{array}{r}0.339^{* * *} \\
(0.004) \\
\end{array}$ & $\begin{array}{r}-0.040 \\
(0.806) \\
\end{array}$ & $\begin{array}{l}0.1687 \\
(0.514) \\
\end{array}$ \\
\hline Government expenditure " & $\begin{array}{r}-0.0231 \\
(0.846)\end{array}$ & $\begin{array}{r}-0.0196 \\
(0.792) \\
\end{array}$ & $\begin{array}{r}0.060 \\
(0.376) \\
\end{array}$ & $\begin{array}{r}-0.0231 \\
(0.846) \\
\end{array}$ \\
\hline Financial crisis & $\begin{array}{c}-0.0877^{*} \\
(0.0757)\end{array}$ & & $\begin{array}{r}-0.065^{* *} \\
(0.041)\end{array}$ & $\begin{array}{r}-0.0877^{*} \\
(0.0757)\end{array}$ \\
\hline Human capital & $\begin{array}{r}0.144 \\
(0.158) \\
\end{array}$ & $\begin{array}{r}0.2104 * \\
(0.055)\end{array}$ & $\begin{array}{r}0.247 * * * \\
(0.005)\end{array}$ & $\begin{array}{r}0.144 \\
(0.158) \\
\end{array}$ \\
\hline
\end{tabular}




\begin{tabular}{|l|r|r|r|r|}
\hline Sargan test (p-value) & 0.259 & 0.473 & 0.260 & 0.259 \\
\hline AR(2) & 0.43 & 0.36 & 0.78 & 0.43 \\
\hline
\end{tabular}

Standard errors in parentheses.

$*, * *, * * *$ - denote significance at $10 \%, 5 \%$ and $1 \%$ respectively

"Variables are used as natural logarithms of the respective values

Period dummies values not shown.

Sargan test null hypothesis: instruments used are not correlated with the residuals. AR(2) null hypothesis: errors in the first difference equation exhibit no second-order serial correlation

The results of the estimates match our expectations to a certain extent. Again, we see that models 1 and 4 give identical results with the expected exception of the lagged dependent variable in model 4. The initial level of GDP has a negative sign in both growth equations and a positive sign in the GDP equation, which corresponds to the OLS panel analysis. It reflects the tendency of these economies toward mutual convergence, which is expected and in line with Rioja and Valev (2004), Gambacorta et al. (2014), etc. Unexpectedly, it seems that these countries have not benefitted from the increased trade openness and one possible explanation might be the likely unfavourable structure of foreign trade of the analyzed countries, consisting of imports of higher value added products and exports of inferior goods. Another explanation could be the increase of foreign trade with China, mainly imports, which poses a heavy competitive burden to the domestic industries. One should have in mind that the proxy used, trade openness, represents a sum of imports and exports, thus providing no indication as to the trade account balance and its trends. However, the results of Mhadhbi (2014) for developing countries and Ductor and Grechyna (2015) even for developed and middle-income countries which also confirm negative impact show that the expected effect of international trade might not be that clear as specified by theory.

Inflation has a positive sign in almost all equations, but it is only significant in the equation using overall liquidity as a proxy for financial development, pointing to a possible conclusion that countries with more expansionary monetary policies have experienced higher growth rates in the analyzed period. Available human capital, as expected, has had a positive impact on economic growth.

The basic variables of interest are those related to financial development. The development of the banking sector, proxied by the total value of loans extended to the private sector has contributed positively to the overall economic development. It is also confirmed in model 3, where it is the only financial sector variable. The same is true for the total amount of liquid assets in the economy. The impact of the securities market has not been significant, although its sign is positive. This is in line with our expectations, since the stock markets in these countries are immature, rather illiquid, volatile and highly vulnerable to internal and external shocks. In many occasions, these markets have been strongly influenced by the influx of foreign portfolio investors and their withdrawal. This outcome also corresponds to the findings of Demirgüç-Kunt et al. (2013), who show that at lower levels of economic development, banks provide more useful functions to the industrial sector, while at later stages, the importance of securities markets increases and substitute the functions previously dominated by banks. Since all the post-transition economies are, or at least, have been during a major part of the analyzed period, less-developed economies, this finding could indicate that they have not yet reached the turning point at which the stock markets would begin to provide their full contribution for the overall economic development. 


\section{CONCLUSIONS}

After three decades of operating under market conditions, the economies of the former socialist countries of CEE and CIS are still coping with the challenges related to the economic transition. One of the most striking issues in this process is the establishment and development of an efficient financial system which would play the same role in the overall economic development comparable to what it does in the developed economies. Starting from a monobank system or centrally controlled banks and no financial markets, this was not an easy going and undemanding process. The study shows that there are signs that the banking sector or the financial system as a whole have played a positive role in the economic development of these countries during the analyzed period. The contribution of the securities markets could not be confirmed yet. It is not surprising having in mind their low liquidity, the poor width of the markets and the episodes of severe capital flights. In addition, the period analyzed, though not very long, involved one major crisis (2008) which could also have affected the results.

The results suggest that these countries as a whole have not yet reached the level at which the benefits of the functioning securities markets positively reflect on growth. They mostly serve as a medium for reallocation of ownership, rather than as mechanisms for efficient allocation of capital. The corporate governance functions that these markets provide in the market-based systems are still absent and the companies are rarely using securities issues as a source of funding. The regulators should therefore pay a lot of attention at increasing the efficiency of the banking system, so that the allocation of capital through bank loans would be optimized and at the same time implement measures to further develop the securities market and the accompanying institutions to provide a functional alternative and a complement to the banking sector. At the same time, considering the widely recognized fact that at earlier stages the role of the securities markets is insignificant, one should not be disappointed by their irrelevant contribution in these countries. One important constraint of this paper is the relatively small sample. This topic needs to be revisited in the future as lengthier time series of data become available and several additional countries provide data so that the sample could be more complete.

\section{REFERENCES}

Arellano M. and Bond S. (1991), "Some Tests of Specification for Panel Data: Monte Carlo Evidence and an Application to Employment Equations", Review of Economic Studies, Vol. 58, pp. 277-297.

Arellano, M. and Bover, O. (1995), "Another look at the instrumental variable estimation of errorcomponents models", Journal of Econometrics, Vol. 68, pp. 29-52.

Blundell, R. and Bond, S. (1998), "Initial conditions and moment restrictions in dynamic panel data models", Journal of Econometrics, Vol. 87 No. 1, pp. 115-143.

Berglöf, E. and Bolton, P. (2002), "The Great Divide and Beyond: Financial Architecture in Transition", Journal of Economic Perspectives, American Economic Association, Vol. 16 No. 1, pp. 77-100.

Bonin, J., Hasan, I. and Wachtel, P. (2008), "Banking in Transition Countries", BOFIT Discussion Paper No. 12/2008, Bank of Finland, Institute for Economies in Transition (BOFIT), Helsinki.

Chinn, M.D. and Ito, H. (2006), "What Matters for Financial Development? Capital Controls, Institutions, and Interactions", Journal of Development Economics, Vol. 81, Issue 1, pp.163-192. Cojocaru, L.E., Falaris, M., Hoffman, S.D. and Miller, J.B. (2016), "Financial System Development and Economic Growth in Transition Economies: New Empirical Evidence from the CEE and CIS Countries", Emerging Markets Finance and Trade, Vo. 52 No.1, pp. 223-236. 
Demirgüç-Kunt, A., Feyen, E. and Levine, R. (2013), “The Evolving Importance of Banks and Securities Markets", The World Bank Economic Review, Vol. 27, Issue 3, pp. 476-490.

Ductor, L. and Grechyna, D. (2015), "Financial development, real sector, and economic growth", International Review of Economics and Finance, Vo. 37, pp. 393-405.

Edwards S. (2001), "Capital Mobility and Economic Performance: Are Emerging Economies Different?", working paper No. 8076, National Bureau of Economic Research, January.

Fink G., Haiss, P. and Vukšić, G. (2009), "Contribution of financial market segments at different stages of development: Transition, cohesion and mature economies compared", Journal of Financial Stability, Vol. 5 No. 4, pp. 431-455.

Fisman R. and Love, I. (2004), "Financial Development and Intersectoral Allocation: A New Approach", The Journal of Finance, Vol. 59 No. 6, pp. 2785-2807.

Fry, M. (1997), "In favour of financial liberalisation", The Economic Journal, Vol.107 No. 442, pp. 754-770.

Gambacorta, L., Yang, J. and Tsatsaronis, K. (2014), "Financial structure and growth", BIS Quarterly Review, Bank for International Settlements, March.

Greenwood J. and Jovanovic, B. (1990), "Financial Development, Growth, and the Distribution of Income", The Journal of Political Economy, Vol. 98 No. 5, Part 1, pp. 1076-1107.

Kenourgios D. and Samitas, A. (2007), "Financial Development and Economic Growth in a Transition Economy: Evidence for Poland”, Journal of Financial Decision Making, Vol. 3 No. 1, pp. 35-48.

Kindleberger C. (1993), A financial history of Western Europe 2ed, Oxford University Press, New York.

King, R. G., R. Levine (1993), "Finance, Entrepreneurship, and Growth-Theory and Evidence" Journal of Monetary Economics, Vol. 32, 3: 513-542.

Koivu, T. (2002), "Do Efficient Banking Sectors Accelerate Economic Growth in Transition Countries?", BOFIT Discussion Paper, No. 14.

La Porta, R., Lopez-de-Silanes, F., Shleifer, A. and Vishny, R. (2000), "Investor protection and corporate governance", Journal of Financial Economics, Vol. 58 No. 1-2, pp. 3-27.

Levine, R. (1997), "Financial development and economic growth: views and agenda", Journal of Econonomic Literature, Vo. 35, pp. 688-726.

Levine, R. and Zervos, S. (1998), "Stock markets, banks and economic growth", American Economic Review, Vol 88, pp. 537-58.

Lewis, A. (1955), The Theory of Economic Growth, Allen and Unwin, London.

McKinnon, R. (1973), Money and Capital in Economic Development, The Brookings Institution, Washington, D.C.

Mhadhbi, K. (2014), "Financial Development and Economic Growth: A Dynamic Panel Data Analysis", International Journal of Econometrics and Financial Management, Vol. 2 No. 2, pp. 48-58.

Mishkin, F.S. (2004), The Economics of Money, Banking, and Financial Markets, The AddisonWesley series in Economics, Pearson.

Petkovski M. and Kjosevski, J. (2014), "Does banking sector development promote economic growth? An empirical analysis for selected countries in Central and South Eastern Europe", Economic Research-Ekonomska Istraživanja, Vo. 27 No. 1, pp. 55-66.

Rajan, R.G. and Zingales, L. (1998), "Financial dependence and growth", American Economic Review, Vol. 88 No. 3, pp. 559-86.

Robinson, J. (1952), The Rate of Interest and Other Essays, Macmillan, London. 
Schumpeter, J. (1912), The Theory of Economic Development, Harvard University Press, Cambridge, MA.

Goldsmith, R. W. (1969), Financial Structure and Development. Yale University Press, New Haven.

Rioja F. and Valev, N. (2004), "Finance and the Sources of Growth at Various Stages of Economic Development", Economic Inquiry, Vol. 42, pp. 27-40.

Sahay, R., Čihák, M., N'diaye, P., Barajas, A., Bi, R., Ayala, D., Gao, Y., Kyobe, A., Nguyen, L., Saborowski, C. and Svirydzenka, K. (2015), Rethinking Financial Deepening: Stability and Growth in Emerging Markets, IMF Staff Discussion Note, International Monetary Fund.

Song F. and Thakor, A.V. (2010), "Financial system architecture and the co-evolution of banks and capital markets", The Economic Journal, Vol. 120, No. 547, pp. 1021-1055. 